\title{
PENGARUH VARIASI LATIHAN TERHADAP PENINGKATAN KETERAMPILAN BERMAIN SEPAK BOLA PADA CLUB PUTRA BAJA FC TAHUN 2017
}

\author{
Abdul Quddus ${ }^{1}$, Karno Dinata ${ }^{2}$, Didik Daniyantara ${ }^{3}$ \\ email: abdulquddus30@yahoo.com ${ }^{1}$, karnodinata11@gmail.com², daniyantara_didik@yahoo.com 3
}

SMK Karya Adi Husada Rakam ${ }^{1}$, Program Studi Pendidikan Jasmani Kesehatan \& Rekreasi, Fakultas Ilmu Pendidikan, Universitas Hamzanwadi ${ }^{2,3}$

\begin{abstract}
Abstrak
Dalam penelitian ini bertujuan untuk mengetahui ada atau tidak Pengaruh Varuasi Latihan Terhadap Peningkatan Keterampilan Bermain Sepak Bola pada Club Puta Baya FC Tahun 2017'?. Dalam penelitian ini metode yang digunakan untuk memperoleh data tersebut adalah metode dokumentasi, dan metode tes perbuatan, yang menjadi populasi adalah anggota Club Sepak Bola Puta Baya FC Tahun 2017 berjumlah 23 orang dengan menggunakan teknik Studi Populasi, yaitu seluruh populasi dijadikan sampel. Rancangan penelitian yang digunakan dalam penelitian menggunakan One group pretest-postest design, dalam desain ini tidak ada kelompok kontrol dan subyek tidak ditempatkan secara acak, terlebih dahulu melakukan pre-test sebelum diberikan perlakuan, dan post-test setelah diberikan perlakuan. Adapun Instrumen dalam pelaksanaan penelitian ini adalah melaksanakan tes keteramplan bemain sepak bola (passing, heading, shotting, drbbling) dan selanjutnya melaksanakan perlakuan atau variasi latihan. Metode analisis data menggunakan analisis statistik dengan menggunakan rumus $t$-test sebagai uji hipotesis penelitian. Hasil analisis diperoleh " $t$ " hitung sebesar 26,06 untuk variasi latihan terhadap keterampilan bermain sepak bola dan sedangkan nilai " $t$ " tabel sebesar 1,717 ("t" hitung > "t" tabel) dengan derajad kebebasan $(\mathrm{df})=\mathrm{N}-1=20-1=19$ dan taraf signifikansi 5\%. Kenyataan ini membuktikan bahwa "t"hitung ' "t"tabel. Sehingga dapat dikemukakan bahwa hipotesis nihil (Ho) ditolak dan hipotesis alternatif (Ha) diterima. Dengan demikian dapat ditarik kesimpulan bahwa: "Ada Pengaruh Variasi Latihan Terhadap Keterampilan Bermain Sepak Bola pada Club Puta Baya FC Tahun 2017”.
\end{abstract}

Kata Kunci: Variasi Latihan, Peningkatan Keterampilan Bermain Sepak Bola

\begin{abstract}
In this study aims to determine whether or not the influence of exercise variation on the Improvement of Football Playing Skills at Club Puta Baya FC 2017? ". In this research the method used to obtain the data is the method of documentation, and the method of action test, which became the population is Club Football Puta Baya FC 2017 amounted to 23 people using population study technique, that is the entire population sampled. The research design used in the study using One group pre-test post design, in this design there is no control group and the subjects are not placed randomly, pre-test before treatment, and posttest after treatment. The instruments in the implementation of this research is to test the skills of playing football (passing, heading, shotting, dribbling) and then carry out the treatment or variation of the exercise. Method of data analysis using statistical analysis by using $t$-test formula as test of research hypothesis. The result of the analysis obtained " $t$ " counted 26,06 for the variation of practice to the skill of playing soccer and while the value of " $t$ " table equal to 1,717 (" $t$ " count $>$ " $t$ " table) with degree of freedom (df) $=N-1=20-1=19$ and $a$
\end{abstract}


significance level of 5\%. This fact proves that " $t$ " counts the " $t$ " table. So it can be argued that the null hypothesis $(\mathrm{Ho})$ is rejected and the alternative hypothesis $(\mathrm{Ha})$ is

Keywourds: Variation of Practice, Increased Soccer Playing Skills

\section{A. Pendahuluan}

Sepak bola adalah permainan yang di mainkan di lapangan yang lebih besar dari pada olahraga lainnya, peraturan permainan mencakup priode waktu $2 \times 45$ menit tanpa time out dan hanya sedikit pergantian dan waktu istirahat 10-15 menit, setiap pertandingan resmi harus dipimpin oleh satu orang wasit profesional dan dua orang pembantu wasit yang sering disebut hakim garis (Rohim, 2008: 29). Permainan sepak bola merupakan salah satu cabang olahraga yang dimainkan oleh dua tim yang dimana 11 orang dalam setiap tim. Sepak bola merupakan salah satu permainan yang sangat mengasikan dan sangat popular diseluruh dunia, khususnya digemari di Indonesia. Pemilihan dan penerapan metode dalam latihan keterampilan bermain sepak bola untuk pemain Putra Baya FC, agar metode latihan yang di terapkan mampu meningkatkan hasil latihan pemain dalam meningkatkan keterampilan bermain sepak bola, maka akan menggunakan variasi latihan drill. Variasi latihan drill adalah bentuk mengembangkan teknik individu pemain dan meningkatkan keterampilan bermain sepak bola (Timo, 2012: 179). Bentuk gerakan yang digunakan dalam penelitian ini adalah dengan variasi latihan drill. Gerakan variasi latihan drill yang digunakan di antaranya adalah slalom dribble latihan untuk meningkatkan dribbling (Mielke, 2007:7), passing berpasangan dengan satu lawan satu untuk latihan meningkatkan passing (Timo, 2012: 179), shotting dengan menunngu giliran untuk latihan meningkatkan shotting (Mielke, 2007:73), heading secara bergantian untuk latihan meningkatkan heading (Mielke, 2007:55). Perkembangan sepak bola khususnya di pulau Lombok dalam hal ini Club Putra Baya FC memang tidak bisa dipungkiri bahwa kemampuan menguasai teknik dasar sepak bola masih sangat kurang, oleh sebab itu hal ini harus mendapat perhatian yang cukup, baik dari pelatih maupun pemain itu sendiri, sehingga dengan di lakukannya perhatian yang cukup, maka para pemain khususnya pemain Club Putra Baya FC akan menjadi lebih baik. Berdasarkan hasil penelitian Paeran Badrun di dalam jurnalnya yang berisi "dengan metode latihan praktek berpasangan bisa untuk meningkatkan kemampuan teknik dasar dalam permainan sepak bola".

\section{B. Metode}

Rancangan penelitian ini menggunakan "Eksperimen One-Group Pretest-Posttest Design". Desain ini terdapat pre-tes, sebelum diberi perlakuan.Dengan demikian hasil perlakuan dapat diketahui lebih akurat, karena dapat membandingkan dengan keadaan sebelum diberi perlakuan. Tetapi pada desain ini tidak ada kelompok kontrol sehingga hasil peningkatan setelah diberikan perlakuan belum pasti berasal dari perlakuan tersebut karena bisa jadi diakibatkan oleh faktor lain. Desain ini dapat digambarkan sebagai berikut:

Tabel 1. Rancangan Penelitian (Sumber: Jaedun, 2011).

$01 \quad \times \quad 02$

Keterangan:

$\mathrm{O} 1$ = Nilai pretest (sebelum diberi latihan Dribling feinting)

$\mathrm{X}=$ Treatmen berupa latihan Dribling Feinting

O2 = Nilai posttest (sesudah diberi latihan Dribling feinting). 


\section{Hasil dan Pembahasan}

Penelitian ini dilakukan selama dua bulan dengan melibatkan semua pemain Putra Baya yang berjumlah sebanyak 23 orang. Adapun langkah-langkah yang dilakukan dalam penelitian ini sebagai berikut: Langkah awal yang dilakukan dalam penelitian ini adalah mempersiapkan persyaratan-persyaratan serta alat-alat yang sekiranya akan menunjang jalannya pelaksanaan penelitian ini. Adapun persyaratan-persyaratan yang peneliti siapkan adalah sebagai berikut: Membuat surat izin penelitian di Fakultas Keguruan dan Ilmu Pendidikan dengan tujuan ke pengurus club sepak bola Putra Baya FC, Memberikan surat izin penelitian kepada pengurus club Putra Baya FC dan kemudian mendapatkan izin penelitian, Menyediakan sarana prasarana penelitian, yaitu: alat tulis, lapangan, stopwatch, pluit, bola, kun, dan alat ukur. Dalam pelaksanaan penelitian ini ada beberapa hal yang akan dibahas antara lain: Dalam penelitian ini, peneliti menggunakan populasi penelitian yang artinya seluruh populasi dijadikan sampel penelitian yaitu seluruh pemain Putra Baya FC yang berjumlah 23 orang. Adapun subyek penelitiannya sebagai berikut: Pelaksanaan tes awal keterampilan bermain sepak bola (pre-test), Sebelum memulai tes peneliti memperkenalkan diri terlebih dahulu dan kemudian menjelaskan prosedur tes kemampuan dribbling, shotting, heading, passing secara teori dan praktik, kemudian peneliti mencatat nama-nama sampel dan dilanjutkan dengan melakukan pemanasan selama 10-15 menit, kemudian dilanjutkan dengan pelaksanaan tes keterampilan bermain sepak bola di tempat yang sudah disediakan. Pelaksanaan tes awal keterampilan bermain sepak bola (post-test) Sebelum memulai tes peneliti menjelaskan prosedur tes kemampuan dribbling, shotting, heading, passing secara teori dan praktik, kemudian dilanjutkan dengan melakukan pemanasan selama 10-15 menit, dilanjutkan dengan pelaksanaan tes keterampilan bermain sepak bola di tempat yang sudah disediakansetelah di berikan program latihan selama 2 bulan.Uji normalitas diujikan pada masing-masing data penelitian yaitu keterampilan bermain sepak bola yang diperoleh pada saat pretest dan posttest. Uji normalitas dilakukan menggunakan rumus Kolmogorov-Smirnov, dan pengerjaannya menggunakan program SPSS16. Data berdistribusi normal apabila nilai Signifikan (Sig) yang diperoleh dari perhitungan lebih besar dari 0,05 .

Tabel 2. Rangkuman Hasil Uji Normalitas

\begin{tabular}{ccccc}
\hline \multicolumn{5}{c}{ Tests of Normality } \\
& Posttest & \multicolumn{3}{c}{ Kolmogorov-Smirnov ${ }^{\mathrm{a}}$} \\
Pretest & & Statistic & Df & Sig. \\
& 55.00 & .222 & 8 & $.200^{*}$ \\
& 56.00 & .250 & 4 &. \\
57.00 & .253 & 3 &. \\
& 59.00 & .260 & 2 &. \\
*. This is a lower bound of the true significance.
\end{tabular}

Berdasarkan tabel di atas di peroleh nilai signifikan dari data preetest, dan data postest sebesar 0,200. Ternyata nilai signifikan yang diperoleh dari masing-masing variabel lebih besar dari 0,05 (signifikan>0,05) sehingga dinyatakan bahwa variabel dalam panelitian ini semuanya berdistribusi normal. Uji homogenitas dilakukan untuk mengetahui kesamaan variansi atau untuk menguji bahwa data yang diperoleh berasal dari populasi yang homogen. Varians dikatakan homogen apabila nilai Sig $>0,05$. 
Tabel 3. Rangkuman Hasil Uji Homognitas Test of Homogeneity Of Variances

\begin{tabular}{cccc}
\hline \multicolumn{5}{c}{ PREE-TEST } \\
Levene & df1 & df2 & Sig. \\
Statistic & & & \\
2.799 & 5 & 16 & .053 \\
\hline
\end{tabular}

Hasil uji homogenitas variabel penelitian di ketahui F hitung kelompok eksperimen 2.799, sedangkan nilai signifikansi yang diperolehsebesar 0,053. Ternyata nilai Signifikan yang diperoleh lebih besar dari 0,05 (Signifikan>0,05), maka dapat disimpulkan bahwa data dalam penelitian ini mempunyai varians yang homogen. Analisis data dilakukan dengan uji-t pada masing-masing data, baik data preetest maupun postest. Hasil analisis dikatakan signifikan apabila thitung $>\mathrm{t}$ tabeldengan $\mathrm{db}(\mathrm{n}-1)$ dan atau nilai siginifikan kurang dari 0,05 pada taraf signifikansi $=0,05$.dengan hasil preetest sebesar 1133 dan posttest 1295 . Pada langkah ini hasil nilai preetest dan postest akan dimasukkan dalam rumus "t-test" sebagai berikut:

$$
\begin{aligned}
& t=\frac{\sum D}{\sqrt{\frac{N \cdot \sum D^{2}-\left(\sum D\right)^{2}}{(N-1)}}} \\
& t=\frac{162}{\sqrt{\frac{23 \cdot 1178-26244}{(23-1)}}} \\
& t=\frac{162}{\sqrt{\frac{27094-26244}{22}}} \\
& t=\frac{162}{\sqrt{38,63}} \\
& t=\frac{162}{6,215} \\
& t=26,06
\end{aligned}
$$

Jadi nilai akhir yang diperoleh dari perhitungan nilai $t$ untuk variasi latihan terhadap keterampilan bermain sepak bola adalah 26,06. Hasil uji t di proleh dari t hitung sebesar 26,06 , dan nilai $t$ table sebesar 1,717 , nilai signifikan sebesar 0,00 . Ternyata $t$ hitung yang di peroleh lebih besar dari t table dan nilsi signifikan kurang dari 0,05. Oleh karena nilai $t$ hitung $>\mathrm{t}$ table $(26,06>1,717)$ dan nilai sig $(0,00<0,05)$, maka dapat disimpulkan bahwa terdapat perbedaan keterampilan bermain sepak bola pada saat pretest dan posttest. Dengan demikian dapat disimpulkan bahwa terdapat pengaruh variasi latihan terhadap keterampilan bermain sepak bola pada club Putra Baya FC tahun 2017. Berdasarkan tabel di atas dapat diketahui bahwa nilai rata-rata pretest sebelum diberi perlakuan dengan metode variasi latihan adalah sebesar 1133, sedangkan nilai rata-rata setelah diberi perlakuan dengan metode variasi latihan adalah sebesar 26,06. Hasil ini menunjukkan bahwa variasi latihan mempunyai pengaruh yang signifikan. Berdasarkan hasil analisis data tersebut, hipotesis nihil (Ho) yang berbunyi: "Tidak Ada pengaruh variasi latihan terhadap keterampilan bermain sepak bola pada club sepak bola Putra Baya FC Tahun 2017", ditolak dan hipotesis alternatif (Ha) yang berbunyi :"Ada pengaruh variasi latihan terhadap peningkatan keterampilan bermain sepak bola pada club sepak bola Putra Baya FC Tahun 2017”, diterima. Berdasarkan hasil 
penelitian yang telah dilaksanakan maka hasil analisis data pretest dan posttest pada subyek penelitian memperoleh peningkatan dalam keterampilan bermain sepak bola pada club sepak bola Putra Baya FC pada tahun 2017. Hal ini dapat dilihat dari perbedaan hasil yang didapatkan oleh para pemain pada saat pretest dengan nilai tertinggi 52, nilai sedang adalah 51 dan nilai terendah adalah 47. Dan posttest dengan nilai tertinggi adalah 60, nilai sedang adalah 55 dan nilai terendah adalah 54. Dari hasil penelitian dan analisa data yang dilakukan dengan menggunakan rumus statistik menunjukkan bahwa tes hasil perhitungan yang diperoleh yaitu 26,06 sedangkan pada t-tabel dengan taraf signifikan 0,05 yaitu 1,717 t-tabel $>\mathrm{t}$-tabel hal ini menunjukkan bahwa t hitung lebih besar dari ttabel. Dengan demikian, maka hipotesis alternatif (Ha) yang di ajukan diterima dan hipotesis nihil (Ho) ditolak.Hal ini berarti "Ada pengaruh variasi latihan terhadap peningkatan keterampilan bermain sepak bola pada clubsepak bola Putra Baya FC Tahun 2017”.

\section{Simpulan}

Berdasarkan dari hasil analisis data dan pembahasan pada uraian sbelumnya telah di peroleh nilai preetest sebesar 1133 dan postest sebesar 1295, bisa di simpulkan terjadi peningkatan hal ini dapat dilihat dari $85 \%$ pemain mendapat kategori cukup, pada saat tes awal dan setelah diberikan perlakuan atau latihan terjadi peningkatan hingga $95 \%$ pemain meningkat sampai kategori baik. Berdasarkan hasil penelitian tersebut dapat ditarik kesimpulan sebagai berikut. Ada pengaruh variasi latihan terhadap peningkatan keterampilan bermain sepak bola pada club sepak bola Putra Baya FC Tahun 2017. Hal ini dapat terlihat nilai t hitung sebesar 26,06 lebih besar dari pada nilai t tabel sebesar 1,717 taraf signifikansi 0,05 .

\section{Daftar Pustaka}

Aminullah, Hari. (2003). Pengaruh Metode Lari Percepatan dan Lari Interval Terhadap Keterampilan Bermain Sepak Bola, Jurnal Megister Administrasi Pendidikan. Volume 3. No. 3 Hal, 3.

Bompa, Tudor. (2007). Theory And Methodologhy Of Training. Toronto: York University.

Chan, Dapit. (2013). Pengaruh Latihan Variasi Passing Terhadap Keterampilan Tekhnik Dasar Sepak Bola pada Siswa Putra SMP Negeri 14 Kota Jambi. Artikel Ilmiah.

Dessianti, Sherly. (2010) Pengertian dan Cara Melakukan Passing dalam Sepakbola. diunduh di http://www.tutorialolahraga.com/2015/09/cara-melakukan-passing-sepak bola.html pada tanggal 15 Desember 2016.

http://erfahza.blogspot.co.id/2014/03/hakikat-sepak-bola.html. Diakses pada tanggal 15 desember 2016.Jam 16.00 wita

Hartono, (2011). Bahan Ajar Basket 1, Gorontalo FIKK. Universitas Gorontalo

Herwin. (2006). Olahraga Menggunakan Bola Besar. Quadra: Perpustakaan Nasional.

Hulfian, Lalu. 2014. Kondisi Fisik dan Tes Pengukuran dalam Olahraga. Mataram. LPP (Lembaga Penelitian dan Pendidikan).

Jaedun, Amat. (2011). Metodologi Penelitian Eksperimen. Pelatihan Artikel Ilmiah. Yogyakarta: LPMP.

Koger, Robert. (2007). Latihan Dasar Andal Sepak Bola Remaja. Klaten: PT. Saka Mitra Kompetensi.

Laksono, Tri Wahyu. (2005). Tingkat Keterampilan Dasar Sepakbola Siswa Peserta Ekstrakurikuler Sepakbola di Smp Negeri 4 Sentolo. Yogyakarta: Program Pascasarjana Universitas Negeri Yogyakarta.

Maksum, Ali. (2009) Metodologi Penelitian Dalam Olahraga. Surabaya. FIK UNESA

Mielke, Danny. (2007). Dasar-dasar Sepak Bola. Pakar Raya. PT: Intan Sejati 
Muhajir. (2006). Pendidikan Jasmani Olahraga dan Kesehatan. PT. Gelora Aksara Pratama: Erlangga.

Mukholid, Agus. (2007). Berlatih Olahraga Menggunakan Bola Besar. Jakarta Timur: PT. Wadah Ilmu Codet .

Mulyono. (2005). Permainan Bola Besar. Padang: Depdikbud.

Mulyono. (2010). Meningkatkan Kemampuan Teknik Dasar Permainan Bola Besar Melalui Metode Praktek Berpasangan. Jurnal Pendidikan jasmani Olahraga Dan Kesehatan. Jilid 2 Nomor 1Hal 77-86.

Naizar, Iqbal Ghulam. (2015), Pengaruh Variasi Latihan Kelincahan Terhadap Keterampilan Dribbling Sepak Bola pada Pemain SSB Taruna Tembakromo Pati

Putra, Michael. (2016). Permainan Sepak Bola. Diunduh di http://olahraga.smansax1edu.com/2015/02/pengertian-permainan-sepakbola.html_pada tanggal 15 Desember 2016.

Raka, Hauri. (2015). Pengaruh Latihan Lari Zig-Zag Terhadap Kemampuan Menggiring dalam Permainan Sepak Bola Peserta Ekstrakulikuler SMA N 3 Sentola Kuloonprogo.

Rohim, Abdul. (2008). Bermain Sepak Bola. Semarang: Aneka Cipta.

Scheunemann, Timo. (2015). Kurikulum Sepak Bola Indonesia. Jakarta: Gheeto TW.

Sodik, Zulfa. (2011). Meningkatkan Keterampilan Menggiring Bola Melalui Metode Bermain Dalam Kelompok-kelompok Kecil Pada permainan Sepak Bola Mini. Jurnal Olahraga Volume 1 Nomor 3.

STKIP Hamzanwadi Selong, 2014. Pedoman Penyusunan dan Pembuatan Skripsi. Selong. Sugiyono, (2012). Metode Penelitian Kuantitatip, Kualitatif dan R\&D. Bandung: Alfabeta.

Sukatamsi. (2003). Tehnik Dasar Bermain Sepak Bola. Yogjakarta: Gajah Mada.

Tirtawirya, Devi. (2006). Ilmu Kepelatihan Dasar. Jakarta: Departemen Pendidikan dan Kebudayaan.

Usman, M. Uzer. .P(2010). Latihan Metode Baru Sepak bola Serangan. Bandung: Pionir Jaya. 